\title{
TRANSFERENCE AND COUNTERTRANSFERENCE IN COGNITIVE BEHAVIORAL THERAPY
}

\author{
Jan Prasko ${ }^{\mathrm{a}, \mathrm{b}, \mathrm{d}, \mathrm{d} *}$, Tomas Diveky ${ }^{\mathrm{a}, \mathrm{b}}$, Ales Grambala ${ }^{\mathrm{a}, \mathrm{b}}$, Dana Kamaradovaa, ${ }^{\mathrm{a}, \mathrm{b}}$, Petr Moznye, \\ Zuzana Sigmundova ${ }^{\mathrm{a}, \mathrm{b}}$, Milos Slepecky ${ }^{\mathrm{f}}$, Jana Vyskocilova ${ }^{\mathrm{c}}$ \\ a Department of Psychiatry, University Hospital Olomouc, I. P. Pavlova 6, 77520 Olomouc, Czech Republic \\ ${ }^{b}$ Psychiatric Clinic, Faculty of Medicine and Dentistry, University Palacky Olomouc \\ c Prague Psychiatric Centre, Ustavni 91, Prague 8 \\ d Centre of Neuropsychiatric Studies, Ustavni 91, Prague 8 \\ e Mental Hospital Kromeriz \\ f Psychagogia s.r.o, Liptovsky Mikulas, Slovakia \\ E-mail:prasko@fnol.cz;
}

Key words: Therapeutic relationship/Transference/Idealization/Disappointment/Anger/Countertransference/Schemas/ Cognitive behavioural therapy/Interpersonal relations

Background. Both patients and psychotherapists can experience strong emotional reactions towards each other in what are termed transference and countertransference within therapy. In the first part of this review, we discuss transference issues. Although not usually part of the obvious language of cognitive behavioral therapy (CBT), examination of the cognitions related to the therapist, is an integral part of CBT, especially in working with difficult patients.

In the second part, we cover counter-transference issues. We describe schematic issues that give rise to therapist counter-transference and explain how this interacts in different types of patient therapist encounter. We also examine ways in which the therapist can use CBT to help him/her modify the countertransference and, in the process, assist the patient.

Methods. PUBMED data base was searched for articles using the key words "therapeutic relations", "transference“, "countertransference", "cognitive behavioral therapy“, "cognitive therapy", "schema therapy", "dialectical behavioral therapy“. The search was repeated by changing the key word. No language or time constraints were applied. The lists of references of articles detected by this computer data base search were examined manually to find additional articles. We also used the original texts of A. T. Beck, J. Beck, M. Linehan, R. Leahy, J. Young and others. Basically this is a review with conclusions about how therapists can manage transference issues.

Results. Transference. The therapist should pay attention to negative or positive reactions towards him/ her but should not deliberately provoke or ignore them. He/she should be vigilant for signs of strong negative emotions, such as a disappointment, anger, and frustration experienced in the therapeutic relationship by the patient. Similarly he/ she should be alert to exaggerated positive emotions such as love, excessive idealization, praise or attempts to divert the attention of therapy onto the therapist. These reactions open space for understanding the patient's past and actual relations outside the therapy. Countertransference. The therapist should be aware of countertransference schemas as they apply to him/her. He/she should monitor his/her own feelings that indicate countertransference. Further, the assistance of and discussion with supervisors and colleagues is useful in regard to countertransference even in experienced therapists. Countertransference can be used as an open window into the interpersonal relations of the patient.

Conclusions. Both the literature and our experience underscore the importance of careful and open examination of both transference and counter-transference issues in CBT and their necessary incorporation in the complete management of all patients undergoing CBT.

\section{INTRODUCTION}

Transference is a phenomenon in psychoanalysis characterized by unconscious redirection of feelings from one person to another, in the case of psychotherapy from patient to therapist. Countertransference refers to transference of feelings from therapist to patient. Both phenomena are based on the human ability to recognise the outside world. Whenever a person perceives something, in order to recognise it, he/she needs to compare the present perception with past experience. Memories, especially pictorial and emotionally laden ones, can be triggered by something in the present which evokes the past and the person will react in a similar way as they did then ${ }^{1}$.

Transference and countertransference feelings/ reactions are a valuable source of information about a patient's (and therapist's) inner world. Some psychotherapists have had or have the perception that transference is not examined in cognitive behavioral therapy (CBT). They believe that the general technical difference between psychodynamic psychotherapy and cognitive behavioral therapy (CBT) is emphasis of the former on transference. This was one of the major misconceptions of CBT that was identified by various experts ${ }^{2-5}$. 
Psychodynamic therapists view transference as a powerful tool in understanding the patient and eventually effecting change. They believe that cognitive behavioral therapists eschew transference as an intervention that would distract the patient from outside relationships and risk therapeutic rupture ${ }^{6}$. Although the interpretation of transference is not a central tool of cognitive therapy, automatic thoughts and feelings related to interactions with the therapist are very much within the scope of exploration and may provide valuable opportunities for testing and modifying dysfunctional automatic thoughts ${ }^{2,7}$. A good therapeutic relationship is an important issue for the effective treatment in cognitive behavioral therapy. Cognitive behavioral therapists generally aim to establish an open collaborative relationship at the start of therapy and then to work directly towards them without paying too much attention to interpersonal issues. Clinical competence, conviction, and consistency seem to predict a more successful psychotherapeutic outcome $e^{8-10}$. However, when working with difficult patients (e.g. patients with personality disorder, hypochondriasis etc.) psychotherapy is rarely strightforward. The dysfunctional schemas, beliefs and assumptions that bias the patient's perceptions of others are likely to bias their perception of the therapist. The dysfunctional interpersonal behaviour strategies, manifest in the patient-therapist relationship. If they are not addressed effectively, interpersonal difficulties arising in the patient-therapist relationship can disrupt the therapy. However, these difficulties also provide the therapist with an opportunity to directly observe an intervention rather than having to rely on the patient's report of interpersonal problems occuring outside the sessions ${ }^{11}$. Therefore transference and countertransference feelings/reactions are a valuable source of information about a patient's (and therapist's) inner world.

\section{TRANSFERENCE FROM THE COGNITIVE BEHAVIORAL POINT OF VIEW}

Although the word "transference" is not part of the jargon of cognitive behavioral therapy, examination of the cognitions related to the therapist apropos past significant relationships is an integral part of assessment and treatment within $\mathrm{CBT}^{12,13}$. The patient's emotional reaction to the dynamics of therapy and therapist are important especially in working with difficult patients. Always alert but not provoking, the therapist should be ready to explore these reactions for more information about the patient's system of thoughts and beliefs. If not explored, possible distorted interpretations persist and may interfere with the collaboration. If exposed, they often provide rich material for understanding the meanings and beliefs behind the patient's idiosyncratic or repetitious reactions. Some forms of therapy depend on the use of transference. Simply stated, transference occurs when the patient superimposes prior experiences on the therapist ${ }^{14}$. The patient may perceive something about the therapists personality, style, demeanor, or appearance that may remind him or her of a significant person in the patient's past, such as a parent; hence, the patient may begin to respond to the therapist as the patient would to that parent. Effective transference is facilitated by the therapist persistently withholding self-disclosure, presenting as a virtually unbiased blank slate (tabula rasa) wherein the patient is free to superimpose (transfer) his or her feelings for a significant person in his or her own life (a parent, spouse, sibling, peer, etc.) onto the neutral therapist ${ }^{15}$. This is not the aim of CBT. Self-disclosure, warm and empathetic atmosphere, collaborative relation and stress on the self-efficacy of the client may pollute this transference potential ${ }^{14}$.

There are many telltale signs of transference. These are the same signs that suggest the presence of automatic thoughts during the session. E.g. there may be a sudden change in the patient's nonverbal behavior: sudden change in expression, abruptly switching to a new topic, stammer, block, pauses in the middle of a train of statements, slumping posture, clenching fists, kicking, tapping foot and so on. One of the most revealing signs is a shift in the patient's gaze, especially if he/she has had a thought but prefers not to reveal it $^{16}$. When asked, the patient may say, "It is not important." The therapist should press the patient nonetheless, gently, as it might be important.

The therapist should pay attention to any negative or positive reactions to him/her that arise but should not deliberately provoke or ignore them. $\mathrm{He} / \mathrm{she}$ should be vigilant for signs of disappointment, anger, and frustration experienced by the patient in the therapeutic relationship. Similarly the therapist should be alert to excessive idealization, praise or attempts to divert the attention of therapy onto the therapist. These reactions open windows into the patient's past and actual relations outside the therapy. The therapist would be unable to view the meanings or beliefs beyond these windows if the arousal of their own affective responses is viewed as a distraction to be controlled, avoided, or suppressed. Hoffart et al. ${ }^{17}$ examined whether therapists' emotional reactions to their patients mediate the effect of personality disorders and interpersonal problem behaviours on the outcome of treatment with a focus on an Axis I disorder and, whether the therapists' reactions mediate the effect of personality disorders on the course of interpersonal problems. Therapists completed a checklist of emotional reactions to individual patients after the end of residential cognitive or guided mastery therapy for 46 inpatients with panic disorder with agoraphobia. The severity of DSMIII-R personality disorder was related to the therapists' insecurity feelings but not to interest or anger. A higher level of therapist insecurity feelings was related to less reduction in self-reported agoraphobic avoidance during treatment, whereas the therapists' emotions were unrelated to symptomatic course after treatment. Therapists' insecurity feelings appeared partly to mediate the relationship between patient severity of personality disorder and persistence of patients' interpersonal dominance and nurturance problems. 
Rossberg et al. ${ }^{18}$ studied the relationship between patients' self-reported personality characteristics, treatment outcome and therapists' countertransference reactions. Eleven therapists filled in the Feeling Word Checklist 58 (FWC-58) for each patient admitted to a day treatment program. The patients completed the Circumplex of Interpersonal Problems (CIP) at admission and discharge. At the end of treatment, the outcome measures were assessed. At the start of treatment, therapists reported fewer feelings of rejection and being on guard in response to patients who reported high avoidant, exploitable, overly nurturing and intrusive CIP subscale traits. At the end of the treatment, the CIP subscales of being domineering, vindictive and cold correlated with fewer positive and more negative countertransference feelings. The study revealed a strong relationship between improvement and countertransference feelings. This study confirms clinical narratives of relationships between the therapists' countertransference reactions and patients' reported interpersonal problems and outcome.

An idealized transference develops quite often, usually at the beginning of the treatment, whereas negative transference typically occurs later. Acute intense transference and countertransference feelings/reactions may serve as indicators of serious character pathology, such as Cluster B personality disorders. Devaluation presents one of the therapist's biggest challenges: conducting therapy and managing resistance with patients who force the therapist into very aggressive and uncomfortable experiences. When these situations arise, the therapist has a twofold task. He or she must tolerate the transference enough not to engage in a countertransferential enactment. Additionally, from this vulnerable vantage point, he or she must help the patient understand both the meaning of and the consequences of devaluations of the therapist ${ }^{19}$.

Table 1. Examples of some kinds of transference and plausible reactions of the therapist.

\begin{tabular}{|c|c|c|c|c|}
\hline $\begin{array}{c}\text { Type } \\
\text { of transfer- } \\
\text { ence }\end{array}$ & Examples of typical thoughts & $\begin{array}{l}\text { Emotional } \\
\text { reactions }\end{array}$ & Behavior & Useful therapeutic reaction \\
\hline $\begin{array}{l}\text { Moderate } \\
\text { positive }\end{array}$ & $\begin{array}{l}\text { The therapist wants to help me, } \\
\text { understand me, is human and } \\
\text { helpful, doing his job very well } \\
\text { - so he help me }\end{array}$ & Nice tune & $\begin{array}{l}\text { Cooperation, willingness to do } \\
\text { homework }\end{array}$ & None \\
\hline $\begin{array}{l}\text { Admiring } \\
\text { - Inde- } \\
\text { pendent }\end{array}$ & $\begin{array}{l}\text { Therapist is great like me. } \\
\text { It's nice to meet with such a } \\
\text { person, he can advise me with } \\
\text { something, of course I can only } \\
\text { help myself. }\end{array}$ & $\begin{array}{l}\text { Nice tune or } \\
\text { euphoria at } \\
\text { meetings }\end{array}$ & $\begin{array}{l}\text { Enjoy discussing with a therapist } \\
\text { opposite positions, slightly com- } \\
\text { petes, homeworks alternately } \\
\text { preparing and not doing, empha- } \\
\text { sizes freedom of relationship }\end{array}$ & $\begin{array}{l}\text { Open narcissistic attitude, discuss the "advantages } \\
\text { and disadvantages" in life, "normalization "- neither } \\
\text { of us is more unique than any other man, insist on } \\
\text { homework }\end{array}$ \\
\hline $\begin{array}{l}\text { Admiring- } \\
\text { dependent }\end{array}$ & $\begin{array}{l}\text { Therapist is great. It is only } \\
\text { himself, who is able to help me } \\
\text { - I am lost without him. I can } \\
\text { do anything with his support. }\end{array}$ & $\begin{array}{l}\text { Euphoric tune } \\
\text { changes with } \\
\text { anxiety about } \\
\text { being left }\end{array}$ & $\begin{array}{l}\text { Try to put themselves into thera- } \\
\text { pist's place, They bring presents, } \\
\text { flatter, do their best to do the } \\
\text { homework- need affirmation that } \\
\text { they did it right, often require } \\
\text { advice, explanation, support. }\end{array}$ & $\begin{array}{l}\text { To strength independent behaviors, assign exercises } \\
\text { such as "independent steps" for homework, discuss } \\
\text { the dependent thoughts and go through the advan- } \\
\text { tages and disadvantages of the dependent attitudes. } \\
\text { Advice, affirmation and further explanation should } \\
\text { not be given. Exposition to independent activities } \\
\text { and tasks. }\end{array}$ \\
\hline Erotic & $\begin{array}{l}\text { Therapist is a perfect (ideal) } \\
\text { partner. Relationship with him } \\
\text { will save me, it would be won- } \\
\text { derful to be with him, make } \\
\text { love with him, to flow into one } \\
\text { another (be in harmony with } \\
\text { him) }\end{array}$ & $\begin{array}{l}\text { Crush on } \\
\text { the therapist, } \\
\text { maybe the } \\
\text { deperson- } \\
\text { alization or } \\
\text { the "trance" } \\
\text { during the } \\
\text { contact with } \\
\text { the therapist }\end{array}$ & $\begin{array}{l}\text { Flirting or shy withdrawal, } \\
\text { wearing showy clothes, amorous } \\
\text { looks towards the therapist, } \\
\text { filtration of the information, i.e } \\
\text { they need to look better than they } \\
\text { really are. }\end{array}$ & $\begin{array}{l}\text { It is not necessary to solve it, as far s it does not } \\
\text { affect the therapy. It flows away spontaneously. In } \\
\text { case it blocks the therapy- open the theme as a } \\
\text { problem, go through the thoughts and realize their } \\
\text { influence on the behavior, discuss sources of this } \\
\text { need" in the past, express clearly and in a sensi- } \\
\text { tive way his/her own attitudes in the therapeutic } \\
\text { relationship. }\end{array}$ \\
\hline $\begin{array}{l}\text { Shy } \\
\text { (appre- } \\
\text { hensive) } \\
\text {-distrustful }\end{array}$ & $\begin{array}{l}\text { Therapist can comment upon } \\
\text { me, can hurt me, he is strong } \\
\text { when he finds out who I am, } \\
\text { he will refuse me and will make } \\
\text { fun of me and will reject me }\end{array}$ & $\begin{array}{l}\text { Fear, anxiety, } \\
\text { shame }\end{array}$ & $\begin{array}{l}\text { Problems with an eye contact, } \\
\text { censorship of what he /she is } \\
\text { willing to share with the therapist. } \\
\text { Does homework anxiously, often } \\
\text { speaks about being worthless, } \\
\text { looks for apologies and explana- } \\
\text { tions, rationalization, unable to } \\
\text { trust. }\end{array}$ & $\begin{array}{l}\text { Often goes away during the therapy, as the trust is } \\
\text { obtained during the therapy, if it persists as a prob- } \\
\text { lem, it should be opened as a problem, work with } \\
\text { the thoughts, look for the possible causes of these } \\
\text { attitudes in the past, the adaptive and maladaptive } \\
\text { aspects, planning the expositions with the aim of } \\
\text { showing the courage to behave in an open way }\end{array}$ \\
\hline Aggressive & $\begin{array}{l}\text { I must show my power (domi- } \\
\text { nance) otherwise I will be } \\
\text { deprived of my freedom and } \\
\text { discernment. It is either him } \\
\text { who wins or me. How dares he! } \\
\text { I must put him down! }\end{array}$ & $\begin{array}{l}\text { Anger, hate, } \\
\text { fear }\end{array}$ & $\begin{array}{l}\text { Aggressive voice as well as his } \\
\text { look, verbal rage, accusations, } \\
\text { blaming, threatening, sometimes } \\
\text { even the physical aggression. }\end{array}$ & $\begin{array}{l}\text { Give the feedback, let the patient know we } \\
\text { understand his feelings, let him express anger and } \\
\text { derogation by the method of negative questioning } \\
\text { and assertive approval or by the means of feedback, } \\
\text { then discuss the attitudes lying behind that, go to } \\
\text { their background, how they are expressed in the } \\
\text { behavior, the advantages and disadvantages. When } \\
\text { finally patient's tension decreases, the therapist } \\
\text { should express his attitude by feedback (to take } \\
\text { patient's behavior separately from his personality } \\
\text { as such). }\end{array}$ \\
\hline
\end{tabular}


Table 1. (Continued)

\begin{tabular}{|c|c|c|c|c|}
\hline $\begin{array}{c}\text { Type } \\
\text { of transfer- } \\
\text { ence }\end{array}$ & Examples of typical thoughts & $\begin{array}{l}\text { Emotional } \\
\text { reactions }\end{array}$ & Behavior & Useful therapeutic reaction \\
\hline Suspicious & $\begin{array}{l}\text { Therapist does me wrong on } \\
\text { purpose, abuses me for his } \\
\text { own needs or for the needs of } \\
\text { somebody else, he is against } \\
\text { me, has hidden motives, does } \\
\text { not play fair. }\end{array}$ & $\begin{array}{l}\text { Anger, fear, } \\
\text { feelings of } \\
\text { threat }\end{array}$ & $\begin{array}{l}\text { He withdraws, does not speak } \\
\text { about himself or only superficial- } \\
\text { ly, can be aggressive indirectly, } \\
\text { does not do homework, drops out } \\
\text { or stops attending the therapy. }\end{array}$ & $\begin{array}{l}\text { Give the feedback, discuss the situation openly, } \\
\text { help to examine, where the sensibility comes from } \\
\text { and to go through the relationships, where it also } \\
\text { occurs. Mapping the sensible attitudes, their advan- } \\
\text { tages and disadvantages, effects on the behavior. } \\
\text { Experimenting with the confidence. }\end{array}$ \\
\hline $\begin{array}{l}\text { Compe- } \\
\text { titive }\end{array}$ & $\begin{array}{l}\text { Can't let him overtop me, I am } \\
\text { better in many things than he } \\
\text { is. I will show him, don't let } \\
\text { him humiliate me. }\end{array}$ & $\begin{array}{l}\text { Tension, } \\
\text { changes of } \\
\text { feelings of } \\
\text { euphoria } \\
\text { anger, envy, } \\
\text { frustration, } \\
\text { according to } \\
\text { the subjective } \\
\text { "score" }\end{array}$ & $\begin{array}{l}\text { Secretly or openly competes, fiery } \\
\text { discuss everywhere, where ex- } \\
\text { pects "competition", rationalizes } \\
\text { non compliance in homeworks }\end{array}$ & $\begin{array}{l}\text { Give the feedback for the specific situations, investi- } \\
\text { gate the competitive thoughts and deeper attitudes, } \\
\text { their sources situations, where they occur, ,to which } \\
\text { behavior they lead to, ,advantages and disadvan- } \\
\text { tages including their effects on the therapy.. }\end{array}$ \\
\hline $\begin{array}{l}\text { Contemp- } \\
\text { tuous }\end{array}$ & $\begin{array}{l}\text { He cannot make it! He is weak, } \\
\text { stupid, he is a fool, etc. How } \\
\text { could he help me? I am the } \\
\text { dominant one in our relation- } \\
\text { ship }\end{array}$ & $\begin{array}{l}\text { Contempt, } \\
\text { impatience, } \\
\text { anger }\end{array}$ & $\begin{array}{l}\text { He despises the therapist, he } \\
\text { cheapens what the therapist does, } \\
\text { refuses to do the homework, } \\
\text { drops out the lessons or stops } \\
\text { attending the therapy }\end{array}$ & $\begin{array}{l}\text { Give the feedback about the particular behavior, } \\
\text { investigate thoughts and attitudes, find their origin, } \\
\text { find how they work in different situations, the } \\
\text { behavior they lead to, advantages and disadvantages } \\
\text { for the life and relationships, what they mean for } \\
\text { the therapy. }\end{array}$ \\
\hline Jealous & $\begin{array}{l}\text { He prefers the others, he does } \\
\text { not care for me. }\end{array}$ & Ager, grief & $\begin{array}{l}\text { Withdrawal or regrets, sometimes } \\
\text { outbursts of anger, measuring the } \\
\text { time of sessions (others and him- } \\
\text { self), monitoring of manifestation } \\
\text { of favor (himself and others). }\end{array}$ & $\begin{array}{l}\text { Ask for the thoughts related to the sorrow (harm- } \\
\text { ing the therapeutic relationship), then help with } \\
\text { opening the thoughts, emotions and behavior } \\
\text { concerning the anger. Go through the reasons in } \\
\text { the past (place in the family as a sibling) and how } \\
\text { they affect the behavior, emotions and relationships } \\
\text { in various life situations, advantages/ disadvantages } \\
\text { for the relationships and life and for the therapy. }\end{array}$ \\
\hline Possessive & $\begin{array}{l}\text { He is here for me, he has to be } \\
\text { there for my disposal anytime. }\end{array}$ & $\begin{array}{l}\text { Feelings of eu- } \\
\text { phoria change } \\
\text { with anger ac- } \\
\text { cording to the } \\
\text { behavior of } \\
\text { the therapist. }\end{array}$ & $\begin{array}{l}\text { He domineers, calls very often, } \\
\text { does not visit the therapist at the } \\
\text { time they agreed on and is angry } \\
\text { when the therapist is not on } \\
\text { disposal. He blames or is verbally } \\
\text { aggressive. }\end{array}$ & $\begin{array}{l}\text { Investigate thoughts and attitudes, find their origin } \\
\text { in the past (the need of possession instead of the } \\
\text { fear of being left by someone), thoughts, emotions } \\
\text { and behavior in various relationships including the } \\
\text { therapeutic one, advantages and disadvantages. }\end{array}$ \\
\hline
\end{tabular}

\section{COGNITIVE ASPECTS OF TRANSFERENCE}

Techniques of explicit formulation are included in cognitive behavioral therapy. Having a clinical formulation that is shared with a patient can help maintain the therapeutic alliance during difficult reenactments ${ }^{1,20}$. In CBT, especially in schema focus therapy, therapists use operationalized core schemas and beliefs as the focus of therapy, targeting transference and maladaptive interpersonal patterns. Developing a CBT case conceptualization of patients is recommended for treating each patient in $\mathrm{CBT}^{4}$; cognitive behavior therapists examine the thoughts, feelings, and behaviors related to a wide range of situations (including reactions to the therapist) and relevant childhood experiences to understand the underlying core beliefs and conditional assumptions of each patient ${ }^{12}$.

Transference interpretation has remained a core ingredient in psychodynamic tradition, despite limited empirical evidence for its effectiveness. In the field of psychoanalysis, the technical use of transference interpretations versus other interpretations has been intensively debated over a period of 100 years. Despite this fact, the research base remains very limited and inconclusive. Only one of eight naturalistic studies has reported a positive correlation between transference interpretations and outcome ${ }^{21}$. There is no study on the efficacy of using transference discussions in CBT. The goal of transference interpretation is sustained improvement in the patient's relationships outside therapy. It seems to be especially important for patients with long-standing, more severe interpersonal problems. Although the central tool of CBT is not interpretation of transference, automatic thoughts and feelings related to interactions with the therapist are very much within the scope of exploration and may provide valuable opportunities for testing and modifying dysfunctional automatic thoughts ${ }^{2,7}$. One of the more common mistakes in CBT, is moving too quickly away from the emotions being expressed about the therapist or the therapy, and failing to sufficiently attend to this rich opportunity for further understanding the patient ${ }^{16}$.

Tact and timing in the exploration of transference reactions are paramount. At the "macro" level of case analysis, formulation represents conceptualization at the level of whole treatment. Case formulation was initially developed in relation to psychodynamic approaches ${ }^{22}$ and shown to be a replicable procedure. Recent work has included explicit formulation techniques in cognitive therapy ${ }^{4}$.

Transference is also influenced by the actual behavior 
of the therapist. Explicit discussion of the patient's ongoing relationship with the therapist is compelling when it is accurate. Focus on the transference makes it possible for the patient (and therapist) to become directly aware of the distinction between reality and fantasy in the therapeutic encounter. However, in brief therapy, transference interpretations may be too anxiety-provoking.

\section{COUNTER-TRANSFERENCE}

Counter-transference occurs when the therapist reacts in complementary fashion to the patient's transference. Attention to emotional reactions of both patient and therapist is a fundamental component of cognitive behavioral therapy, especially during the process of therapy with difficult patients. Despite the manualization of treatment and emphasis on techniques and pharmacotherapy, countertransference exists. No therapist is free of countertransference. To guide patients effectively in discovering their thoughts and expressing their feelings, the therapist needs to have a foundation of skills for recognizing, labeling, understanding, and expressing his/ her own emotions ${ }^{16}$. To understand our own limitations, our own resistance to change, is necessary to discover more about the patient and ourselves; as we learn how the patient's behavior affects our own countertransference, we are also learn about how the patient affects others ${ }^{23}$. Rather than having no feelings, or being an expert at repression, the cognitive therapist is attuned to personal emotions that might affect the therapy environment. Just as the therapist would encourage a client to do, cognitive behavioral therapists use awareness to their own physical sensations and subtle mood shifts as cues, suggesting the presence of automatic thoughts. Any changes in the therapist's typical behavior might signal an emotional reaction and associated automatic thoughts, such as talking in a commanding (or hesitating) tone of voice, increased frequency of thoughts about a client outside sessions, or perhaps avoidance of returning a client's phone call or tardiness in starting or ending a session.

\section{TYPES OF COUNTER-TRANSFERENCE}

Betan et al. ${ }^{24}$ studied a national random sample of 181 psychiatrists and clinical psychologists in North America. Each completed a battery of instruments on a randomly selected patient in their care, including measures of axis II symptoms and the Countertransference Questionnaire, an instrument designed to assess clinicians' cognitive, affective, and behavioral responses in interacting with a particular patient. Factor analysis of the Countertransference Questionnaire yielded eight clinically and conceptually coherent factors that were independent of clinicians' theoretical orientation: 1) overwhelmed/disorganized, 2) helpless/inadequate, 3) positive, 4) special/overinvolved, 5) sexualized, 6) disengaged, 7) parental/protective, and 8) criticized/mistreated. The eight factors were associated in predictable ways with axis II pathology. An aggregated portrait of countertransference responses with narcissistic personality disorder patients provided a clinically rich, empirically based description that strongly resembled theoretical and clinical accounts.Countertransference patterns were systematically related to patients' personality pathology across therapeutic approaches, suggesting that clinicians, regardless of therapeutic orientation, can make diagnostic and therapeutic use of their own responses to the patient ${ }^{24}$.

In some cases, the focus on the patient's problems may allow the therapist to compartmentalize and avoid his/her own personal problems or allow the therapist to displace his/her conflicts with others onto the patient ${ }^{23}$. Some people are attracted to being therapists because it allows them a sense of competence, superiority, and apparent efficacy. This illusion of competence may allow the therapist to unconsiously pursue other goals, such as the need to have power or control, or the need to compartmentalize, intellectualize, and isolate oneself from one's own problems.

Table 2. Examples of the counter-transference and possible strategies for a change.

\begin{tabular}{|c|c|c|c|c|}
\hline $\begin{array}{l}\text { Type of } \\
\text { counter- } \\
\text { transfer- } \\
\text { ence }\end{array}$ & $\begin{array}{c}\text { Examples of typical } \\
\text { thoughts }\end{array}$ & $\begin{array}{l}\text { Emotional } \\
\text { reactions }\end{array}$ & Behavior & Strategies of change \\
\hline $\begin{array}{l}\text { Moderate } \\
\text { positive }\end{array}$ & $\begin{array}{l}\text { I like him, he is nice, } \\
\text { good cooperation with } \\
\text { him, he will do well. }\end{array}$ & Nice tune & Cooperation, support, empathy & None \\
\hline Admiring & $\begin{array}{l}\text { That person is special } \\
\text { (especially beautiful, } \\
\text { original, intelligent, etc.) }\end{array}$ & $\begin{array}{l}\text { Admiration, } \\
\text { fascination }\end{array}$ & $\begin{array}{l}\text { Therapist does not make appropriate } \\
\text { examinations, does not conduct the } \\
\text { therapy. Possible non-compliance of } \\
\text { the patient is deprecated, does not } \\
\text { require patient's homework, tends to } \\
\text { talk about the exceptional proper- } \\
\text { ties of the patient }\end{array}$ & $\begin{array}{l}\text { Clarify own attitudes, their background, the effect } \\
\text { on the behavior, advantages + disadvantages for the } \\
\text { therapy. Supervision needed. "Normalization of the } \\
\text { therapy": conduct the same way like the others. In case } \\
\text { that the behavior is impossible to change and make a } \\
\text { standard therapy, necessary to open that problem with } \\
\text { the patient or the patient should change the therapist }\end{array}$ \\
\hline $\begin{array}{l}\text { Over- } \\
\text { protective }\end{array}$ & $\begin{array}{l}\text { He cannot make deci- } \\
\text { sions on his own, Leeds } \\
\text { help, advice, it will be my } \\
\text { fault, if something wrong } \\
\text { happens to him. }\end{array}$ & $\begin{array}{l}\text { Fear, inse- } \\
\text { curity }\end{array}$ & $\begin{array}{l}\text { He gives advice, protects, ensures, } \\
\text { takes control over the patient, does } \\
\text { not allow patient's independent } \\
\text { decision making, doubts patient's } \\
\text { abilities }\end{array}$ & $\begin{array}{l}\text { Clarify own attitudes, their background, the effect } \\
\text { on the behavior, advantages + disadvantages for the } \\
\text { therapy. Supervision needed. Stop the directive leading } \\
\text { of the therapy, let the patient plan things, stop ensur- } \\
\text { ing. Otherwise the patient should change the therapist. }\end{array}$ \\
\hline
\end{tabular}


Table 2. (Continued)

\begin{tabular}{|c|c|c|c|c|}
\hline Erotic & $\begin{array}{l}\text { He/ she is attractive. I } \\
\text { would feel nice with him/ } \\
\text { her. The only problem is } \\
\text { his/her lack of tender- } \\
\text { ness (sex, attention). Has } \\
\text { sexual dreams (imagina- } \\
\text { tion) about the patient. }\end{array}$ & $\begin{array}{l}\text { Fascination, } \\
\text { "trance" or } \\
\text { depersonal- } \\
\text { ization dur- } \\
\text { ing the time } \\
\text { they meet }\end{array}$ & $\begin{array}{l}\text { He flirts, is over-protective, "unwill- } \\
\text { ing" touches, speaks often about } \\
\text { sex, offers "sexual therapy" in the } \\
\text { worst case and has an affair with } \\
\text { the patient }\end{array}$ & $\begin{array}{l}\text { Stop rationalization of the seductive behavior, stop it } \\
\text { completely, admit own counter- transference, find su- } \\
\text { pervision. Realize own motives, their background, the } \\
\text { effect on the behavior, advantages + disadvantages for } \\
\text { the therapy Otherwise the patient should change the } \\
\text { therapist. Even after the change, the therapist should } \\
\text { not have a sexual affair with the patient. }\end{array}$ \\
\hline $\begin{array}{l}\text { Appre- } \\
\text { hensive }\end{array}$ & $\begin{array}{l}\text { He can hurt me, make } \\
\text { fun of me, rouse me, } \\
\text { show me I am worthless, } \\
\text { stupid, etc. }\end{array}$ & $\begin{array}{l}\text { Fear, anxi- } \\
\text { ety, shame. }\end{array}$ & $\begin{array}{l}\text { He speaks quietly, cannot keep the } \\
\text { distance, the leading of the therapy } \\
\text { leaves on the patient, is not active in } \\
\text { the therapy ( he calls it "empathic } \\
\text { leadership". He is afraid to say what } \\
\text { he thinks, does not discuss the } \\
\text { alternatives with the patient }\end{array}$ & $\begin{array}{l}\text { Work on the self-confidence and self-acceptance, } \\
\text { help the patient to process the transference reaction. } \\
\text { Supervision always needed. Otherwise the patient } \\
\text { should change the therapist }\end{array}$ \\
\hline $\begin{array}{l}\text { Aggressive } \\
\text { (invasive) }\end{array}$ & $\begin{array}{l}\text { He is a psychopath, an } \\
\text { ignorant person (does } \\
\text { not try hard enough, } \\
\text { wants only advantages, } \\
\text { secondary benefits, etc). } \\
\text { He is annoying. I will } \\
\text { show him! }\end{array}$ & $\begin{array}{l}\text { Anger, } \\
\text { resonance }\end{array}$ & $\begin{array}{l}\text { He moralizes, preaches, minimizes } \\
\text { the needs of the patient, does not } \\
\text { have time for the patient. He is rude } \\
\text { to the patient, yells at him. }\end{array}$ & $\begin{array}{l}\text { Realize his own aggressive attitudes and behavior, stop } \\
\text { to deny or rationalize them. Clarify their background, } \\
\text { the effect on the behavior, advantages + disadvantages } \\
\text { for the therapy. Otherwise the patient should change } \\
\text { the therapist. }\end{array}$ \\
\hline Distrustful & $\begin{array}{l}\text { What does he want actu- } \\
\text { ally? He has some hidden } \\
\text { intentions against me! }\end{array}$ & $\begin{array}{l}\text { Appre- } \\
\text { hension, ten- } \\
\text { sion, anger }\end{array}$ & $\begin{array}{l}\text { Withdrawal, only "formal coopera- } \\
\text { tion with the patient, waiting for } \\
\text { hidden motives, tries to cancel the } \\
\text { therapy }\end{array}$ & $\begin{array}{l}\text { Work on the self-confidence and self-acceptance } \\
\text { Supervision needed. To process own attitudes, their } \\
\text { origin and effects. If necessary, let the patient chase } \\
\text { the therapist }\end{array}$ \\
\hline $\begin{array}{l}\text { Compe- } \\
\text { titive }\end{array}$ & $\begin{array}{l}\text { Do not let him think, he } \\
\text { will overtop me. }\end{array}$ & $\begin{array}{l}\text { Tension } \\
\text { changes with } \\
\text { the pride } \\
\text { (vanity) }\end{array}$ & $\begin{array}{l}\text { Competition with the patient in the } \\
\text { opinions, in "who is right", prides } \\
\text { himself, he is not very supportive, } \\
\text { empathic }\end{array}$ & $\begin{array}{l}\text { Work on the self-confidence and self-acceptance } \\
\text { Supervision needed. To process own attitudes, their } \\
\text { origin and effects. If necessary, pass the patient to } \\
\text { other therapist }\end{array}$ \\
\hline Derogatory & $\begin{array}{l}\text { He his a jackass, weak- } \\
\text { ling, dumb, hysterical } \\
\text { person, etc.) I am fed up } \\
\text { with him bored,, I wish he } \\
\text { would not annoy me. }\end{array}$ & $\begin{array}{l}\text { Contempt, } \\
\text { boredom, an- } \\
\text { ger, vanity }\end{array}$ & $\begin{array}{l}\text { He gives conceptive advice mini- } \\
\text { mizes the attitudes and problems of } \\
\text { the patient, make fun of him, does } \\
\text { not have the time for him, is very } \\
\text { inpatient, does not let the patient } \\
\text { finish what he wanted to say, does } \\
\text { not listen properly. }\end{array}$ & $\begin{array}{l}\text { To work on his/her own relationships, attend the psy- } \\
\text { chotherapeutic training or to attend a new one in case } \\
\text { experience from the previous is not sufficient enough. } \\
\text { To process own attitudes, their origin and effects. If } \\
\text { necessary, pass the patient to other therapist }\end{array}$ \\
\hline
\end{tabular}

Therapist countertransference feelings may be informative about the entire treatment process of the patient. It has generally been recognized that countertransference vicissitudes play an extremely important role in psychotherapy of patients especially with hypochondriacal and borderline patients, at one or another phase of the treatment ${ }^{25}$. At critical points in the development of transference and countertransference and their interaction, the therapist's recognition of and capacity to deal with countertransference issues become crucial to the treatment progression. According Leahy ${ }^{23}$ typical problems in countertransference include following:

- Ambivalence about using techniques because of fears of alienating the patient;

- Guilt or fear over the patient's anger;

- Feeling of inferiority when working with narcissistic patients;

- Discomfort if the patient is sexually attractive;

- Inability to set limits on sexually provocative or hostile patients;

- Overextending therapy sessions;

- Lack of assertion in collecting fees or enforcing policies;

- Inhibition in taking an adequate sexual history;

- Anger at patients who make phone calls between sessions;

- Catastrophizing the issue of hospitalizing a patient.
When patients present with issues such as abandonment, dependency, devaluation, demandingness, sexual preoccupations, abuse, betrayal, or exploitation of others, they may arouse your own feelings and vulnerabilities about these issues ${ }^{23}$.

\section{COGNITIVE ASPECTS OF COUNTER- TRANSFERENCE}

The therapist uses all of the automatic thought distorsions in countertransference: "This patient is hysterical." (labeling); "He wants only secondary gains." (mind reading); "He'll never get better." (fortune telling); "He's made no improvement." (all-or-nothing thinking); "It's my mistake the patient is no better." (all-or-nothing thinking); "He should do homework" (shoulds); "He won't get better." (overgeneralization)

\section{Countertransference schemas}

The therapist's individual schemas will affect the countertransference.There are probably as many schemas as there are adjectives to describe people. Many therapists display more than one schema. Moreover some patients are more likely to activate certain schemas than others. Leahy ${ }^{23}$ describes these therapist schemas: 
- Demanding standards: Anankastistic or perfectionistic therapists often view patients as irresponsible, selfindulgent, and lazy. They believe that the expression of emotions, or even uncertainty, is devastating. They have difficulty expressing warmth and empathy toward patients and place a great deal of emphasis on "logic" and "rationality". The patient may feel that the therapy is simply an opportunity for the therapist to show that he or she is smarter than the patient. Perfectionistic therapists may attempt to compensate his/her underlying feelings of incompetence and worthlessness by demanding perfect performance from self and patient. A typical sequence of automatic thought can be: "My patient is not getting better $\rightarrow$ I'm not doing my job $\rightarrow$ I'll be exposed as a fraud $\rightarrow$ I'm a failure $\rightarrow$ I can't accept any failure in myself." In some cases the therapist with demanding standards can compensate for his/her perfectionism by demanding more and more from the patient.

- Abandonment: the therapist with an abandonment schema will be worried that if he/she confronts the patient, then the patient will leave the therapy. Premature termination of the therapy is interpreted as a personal rejection of the therapist. Therapists concerned about abandonment issues can behave in many different forms that reflect countertransference: for example on the one hand, excessive caretaking of the patient, or on the other, avoidance of entering into a meaningful therapeutic relationship. Excessive caretaking takes the form of trying to protect the patient from any difficulties and taking on the patient's problems as the therapist's own to solve. Therapists who avoid attachment on the other hand, often focus more on superficial techniques than on more meaningful personal issues. This type of therapist avoids difficult topics with patients and refrains from using anxietyprovoking interventions, such as exposure techniques. They often personalize the patient's lateness, failure to show up for a session, or lack of interest in therapy. Patient's resistance can be seen as a personal rejection.

- Special, superior person: the narcissistic therapist views therapy as an opportunity to show of his/her special talents. Therapy with the resistant patient may begin with grandiose hopes, expressed by the therapist that the patient has finally found the "right therapist". The therapist's investment in his/her own image as being a special, superior therapist may result in his/her siding with the patient to vilify all the other therapists who have "failed" the patient. This therapist feels entitled to having the cooperation and adulation of the patient. This may result in the therapist encouraging boundary violations by the patient or, in some case, the therapist himself/herself may initiate these boundary violations. As the therapeutic relationship unfolds - if the patient does not make rapid progress - the narcissistic therapist may grow bored with, angry at, or punitive towards the patient. He may label the patient "He's a borderline, histrionic, paranoid, hypochondriacal..." Rather than empathize with the patient's understanable frustration with lack of progress, the therapist may turn on the patient, blaming the patient for a lack of desire to improve. To modify the narcissistic perspective, one needs to ask one question: "What would your life be like if you had to walk in the shoes of this patient?"

- Need for approval: The "pleasing" therapist may be highly skilled in showing empathy for the patient. He/ she wishes to make the patient feel good regardless of what is going on, is averse to any expression of anger or disappointment by the patient. The warmth and empathy of such a therapist are much appreciated by many patients but he/she has difficulty recognizing that borderline patients are very angry. This type of therapist will avoid raising questions about the patient's substance abuse, anger, resistance, and selfdefeat. These topics are viewed as too disturbing for the patient, and therefore as not appropriate. Patients may act out by missing sessions, showing up late, or not doing homework, but the high-need-for-approval therapist, who does not want to cause a "conflict" communicates the idea that acting-out behavior is acceptable. One therapist found it difficult to make the decision to hospitalize a suicidal patient because of his/her concern that the patient would get angry with him/her. The therapist may find that the patient's anger is difficult to tolerate. He/she can personalize the patient's behavior and viewed the patient's disapproval as a sign of his/her own failing. His/her assumption was, "If the patient is angry at me, it means that I failed."

\section{SELF-CORRECTION OF COUNTER- TRANSFERENCE}

By anticipating and paying attention to such countertransferential responses, CBT affords the therapist the opportunity to recognize and manage such responses, which reduces the therapist's risk of retaliatory acting out ${ }^{7}$.

Throughout the process of providing therapy, in addition to tending to the patient's expressions, the therapist has to make an effort to monitor his/her reactions to the content of the sessions. Therapist must take special care to recognize his/her strong emotional reactions to patient, both positive and negative; this is an opportunity to ask him/herself how much of what the patient is processing matches the therapist $\mathrm{s}$ prior experiences or preexisting opinions.

The therapist monitoring his/her (positive and negative) feelings, must be aware of these reactions:

- Dreading or happily anticipating session with the patient;

- Having exceptionally strong hateful or loving feelings towards a patient;

- Wanting to end sessions early or extend sessions;

- Strongly wishing for or dreading termination.

The first step in managing counter-transference is the therapist recognizing that his/her feelings toward a patient are unusually strong, either positive or negative. It is use- 
ful to take some time, perhaps outside the therapeutic environment, to patiently ask some introspective questions:

- What are my emotional reactions to this patient?

- Are they somewhat exaggerated?

- What is making me like or dislike this patient?

- What issues do I want or not want to discuss with this patient?

- What is making me feel uncomfortable?

- What were some signs of the patient's pathology that I had missed? What was it about me that made me miss them?

A second step may involve seeking out consultation with a supervisor to help delve deeper into addressing and potentially resolving the source of strong countertransference feelings.

E.g. the therapist may find himself/herself frustrated, angry, anxious, or threatened by the patient's demand for validation. With the work with own thoughts he/she can recognize for instance ${ }^{23}$ : "This patient doesn't really want to get better. All she wants to do is whine. She's keeping me from getting my job done. I'm going to look like I'm incompetent because she won't do what she should do. This patient is just irrational. She shouldn't be irrational.“ It is immensely stress reducing and helpful to the patient's therapy when the therapist can identify and challenge these negative countertransference thoughts. Challenges to these thoughts include the following: "It's irrational to think people should be rational all the time." "All of us need validation some of the time." Reflecting, caring, showing curiosity and respect, and being a good listener are interventions.“

In order to examine the countertransference, the therapist should examine the kinds of life problems that he/she typically has. Is he/she someone who is concerned about rejection or abandonment? Then he/she should examine how these issues arise in his/her contact with patients. Is he/she someone who always has to be "right"? Then he must examine how he/she may be trying to defeat patients in debates, and thereby invalidate them. Is he/she someone who is afraid of failing, because he/she thinks that success or failure indicates how worthwile he/she is? Then he/she must examine how he/she may be afraid of dealing with difficult patients or afraid of taking chances in therapy.
The way the therapist views or deals with therapyrelated thoughts and emotions may need some cognitive restructuring to reduce intensity of negative affect or to maintain adequate focus on therapy goals and objectives ${ }^{16}$. It may be useful to contront any fears about therapist emotions being "mistakes" or indications of failure in therapy and instead focus on ways of understanding the emotional antecedents. Therapist reactions can stem from a number of sources, including cultural of value-related beliefs, the therapist's view of his/her professional role, and unique learning history, as well as from the interactions with the patient's problematic behaviors ${ }^{26}$. The therapist can also use a self-directed inquiry of thoughts about a session, a situation or working with a particular patient or problem and log these thoughts into a dysfunctional thought record.

Especially in preparing to work professionally with patients suffering from personality disorders, hypochondria or somatoform disorders, the therapist needs to be especially careful to be nonjudgmental. Once the therapist has made the diagnosis, it is much better to avoid labels and think in terms of beliefs, core and conditional schemas, predictable reactions, behaviors and so forth. By trying to put him-/herself in the patient's shoes, perhaps imaging him-/herself with the same set of sensitivities, sense of helplessness, and vulnerability - the therapist can better understand the patient. At the same time, the therapist has to be on guard not to become so involved with the patient's problems that objectivity is lost.

\section{COUNTER-TRANSFERENCE AND SUPERVISION}

Having a formulation shared with the patient can help maintain the therapeutic alliance during difficult re-enactments; or, in supervision, help understand potential re-enactments ${ }^{27}$. Ongoing discussion of the therapy with colleagues and with supervisor is valuable (even for experienced therapists) and is built into those therapies that have been empirically validated ${ }^{28}$. Such discussions enhance the therapist' $s$ ability to clarify the patient's transference and contain counter-transference anger and resentment ${ }^{29}$.

Table 3. Therapist's Dysfunctional Thoughtr Record ${ }^{16}$.

\begin{tabular}{|c|c|c|c|}
\hline Situation & Emotion & Automatic thoughts & Rational response \\
\hline $\begin{array}{l}\text { Patient arrives late; per- } \\
\text { sists with dramatic story- } \\
\text { telling; breake into sobs } \\
\text { when I redirecte to agenda } \\
\text { setting. }\end{array}$ & $\begin{array}{l}\text { Frustrated } \\
\text { Disappointed } \\
\text { Uncertain } \\
\text { Embarrassed }\end{array}$ & $\begin{array}{l}\text { This patient will never } \\
\text { get is! } \\
\text { We are making no prog- } \\
\text { ress using cognitive be- } \\
\text { havioral therapy! } \\
\text { I don't know what to do } \\
\text { next. I must be ineffec- } \\
\text { tive with the approach. }\end{array}$ & $\begin{array}{l}\text { Contempt on my part will not help, so I could avoid such eter- } \\
\text { nalized judgments and be more sympathetic. She is showing } \\
\text { more skill in labeling affect, and identifying thoughts. Also, } \\
\text { I'm focusing on the importance of making a list when her } \\
\text { obvious priority is interpersonal support. I need to respect } \\
\text { her values, help her learn to define problems, and not give up. } \\
\text { Just because I feel uncertain does not mean I am ineffec- } \\
\text { tive, or have commited any shameful action. My discomfort } \\
\text { comes from believing all patients must change quickly, and } \\
\text { if they don't it's my fault. Does it make sense that an effec- } \\
\text { tive therapist "never" feels uncertain? I can brainstorm some } \\
\text { options to try next. }\end{array}$ \\
\hline
\end{tabular}


Supervision should support the therapist, give another perspective to problem-solve difficult clinical dilemmas, bolster theoretical understanding to comprehend the patient's current issues, and assist the therapist in maintaining a benevolent, caring, and curious attitude to the patient's vicissitudes. Effective supervision related to the therapy should provide a safe place for the therapist to disclose feelings and attitudes ${ }^{28}$.

Appreciation for the concept of transference might inform the cognitive behavior therapist's understanding of a patient's dysfunctional automatic thoughts and feelings.

\section{CONCLUSION}

The literature shows and it is our experience that both transference and counter-transference issues should be examined carefully and openly in CBT and must be an integral component of the complete management of each patient undergoing CBT. Analysis of transference aims to improve interpersonal functioning. Transference elaborations in CBT seem to be especially important for patients with long-standing problematic interpersonal relationships. Specifically, those patients who need to improve the benefit the most.

Countertransference can be one of the most useful tools in helping patients by providing a window into the "real-world effects" that the patient has outside the therapy. This can be helpful in diagnosing his/her problem and helping the patient understand how his/her behavior may affect others.

\section{AKNOWLEDGEMENTS}

This paper was supported by the research grant IGA MZ CR NS 9752- 3/2008.

\section{REFERENCES}

1. Goin MK. A current perspective on the psychotherapies. Psychiatric Services 2005; 56:255-257.

2. Beck JS. Cognitive Therapy: Basics and Beyond. New York, Guilford 1995.

3. Beck AT, Rush AJ, Shaw BF, Emery G. Cognitive Therapy of Depression. New York, Guilford 1979.

4. Persons J. Cognitive Therapy in Practice: A Case Formulation. New York, WW Norton 1989.

5. Gluhoski V: Misconceptions of cognitive therapy. Psychotherapy 1994; 31:594-600

6. Cutler JL, Goldyne A, Devlin MJ, and Glick RA. Comparing cognitive behavioral therapy, interpersonal psychotherapy, and psychodynamic psychotherapy. Am J Psychiatry 2004; 161:1567-1573.

7. Young JE, Weishaar ME, and Klosko JS. Schema Therapy: A Practitioner's Guide. New York, Guilford 2003.
8. Frank JD, and Frank JB: Persuasion and Healing. A Comparative Study of Psychotherapy. Baltimore, Johns Hopkins University Press 1991.

9. Joyce AS, Piper WE. The immediate impact of transference in short-term individual psychotherapy. Am J Psychother 1993; 47:508-526.

10. Wampold BE. The Great Psychotherapy Debate: Models, Methods, and Findings. Mahwah, NJ, Lawrence Erlbaum Associates 2001.

11. Linehan MM. Dialectical behavioral therapy in groups: Treating borderline personality disorders and suicidal behavior. In: Brody CM (ed), Women in groups. New York, Springer 1987.

12. Sareen J, and Skakum K. Defining the core processes of psychotherapy. Am J Psychiatry 2005; 162:1549.

13. Giesen-Bloo J, van Dyck R, Spinhoven P, van Tilburg W, Dirksen C, van Asselt T, Kremers I, Nadort M, Arntz A. Outpatient psychotherapy for borderline personality disorder: randomized trial of schema-focused therapy vs transference-focused psychotherapy. Arch Gen Psychiatry 2006; 63:649-658.

14. Knapp H. Therapeutic Communication. Developing Professional Skills. Sage Publications, Los Angeles 2007.

15. Breuer J and Freud S. Studies on hysteria. London: Hogarth Press 1955 (Original work published in 1895).

16. Beck AT, Freeman A, Davis DD and Associates: Cognitive therapy of Personality Disorder. The Guilford Press, New York 2004.

17. Hoffart A, Hedley LM, Thornes K, Larsen SM, and Friis S. Therapists' emotional reactions to patients as a mediator in cognitive behavioural treatment of panic disorder with agoraphobia. Cogn Behav Ther 2006;35(3):174-82.

18. Rossberg JI, Karterud S, Pedersen G, and Friis S. Specific personality traits evoke different countertransference reactions: an empirical study. J Nerv Ment Dis 2008; 196:702-708.

19. Robbins B. Under attack: devaluation and the challenge of tolerating the transference. J Psychother Pract Res 2000; 9(3):136-141.

20. Spinhoven P, Giesen-Bloo J, van Dyck R, Kooiman CG, and Arntz A. The therapeutic alliance in schema-focused therapy and transference-focused psychotherapy for Borderline Personality Disorder. J Consul Clin Psych 2007; 75:104-115.

21. Høglend P. Analysis of transference in psychodynamic psychotherapy: a review of empirical research. Can J Psychoanal 2004; 12:279-300.

22. Luborsky L. Principles of Psychoanalytic Psychotherapy: A Manual for Supportive-Expressive (SE) Treatment. New York. Basic Books 1984.

23. Leahy RL. Overcoming Resistance in Cognitive Therapy. The Guilford Press, New York 2003.

24. Betan E, Heim AK, Zittel Conklin C, Westen D. Countertransference phenomena and personality pathology in clinical practice: an empirical investigation. Am J Psychiatry. 2005; 162(5):890-898.

25. Meissner WW. Notes on countertransference in borderline conditions. Int J Psychoanal Psychother 1982-1983; 9:89-124.

26. Kimmerling R, Zeiss A and Zeiss R. Therapist emotional responses to patients: Building a learning-based language. Cogn Behav Pract 2000; 7:312-321.

27. Margison FR, Barkham M, Evans C, McGrath G, Clark JM, Audin $\mathrm{K}$, and Connell J. Measurement and psychotherapy: Evidencebased practice and practice-based evidence. Br J Psych 2000; 177:123-130.

28. Gunderson JG, and Links PS: Borderline Personality Disorder. A Clinical Guide. American Psychiatric Publishing, Inc. Washington 2008 .

29. Gabbard GO and Wilkinson SM. Management of Countertransference With Borderline Patients. American Psychiatric Press, Washington, DC, 1994. 
